\title{
Perubahan Penggunaan Lahan Terhadap Banjir di Kawasan Daerah Aliran Sungai Maros
}

\section{The Effect of Land Use Changes on Floods in the Maros Watershed Area}

\author{
Muhammad Ridwan A Latief ${ }^{1}$, Roland A. Barkey², Muh. Iqbal Suhaeb ${ }^{3}$ \\ ${ }^{1}$ Magister Perencanaan Wilayah dan Kota Program Pascasarjana Universitas Bosowa \\ ${ }^{2}$ Lab. Perencanaan dan Sistem Informasi Kehutanan, Fakultas Kehutanan, Universitas Hasanuddin \\ ${ }^{3}$ Program Studi Perencanaan Wilayah dan Kota, Program Pascasarjana, Universitas Bosowa \\ E-mail: iwanlatief0471@gmail.com
}

Diterima: 20 Februari 2021/Disetujui 07 Juni 2021

\begin{abstract}
Abstrak. Kawasan perkotaan di Kabupaten Maros dilalui oleh Sungai Maros. Aliran Sungai Maros mengalir menuju Selat Makassar dan merupakan muara bagi sungai-sungai lain di bagian hulu. Sungai Maros yang melalui kawasan perkotaan memiliki daerah aliran sungai yang sangat rentan untuk dialihfungsikan. Pertumbuhan alih fungsi lahan non terbangun menjadi terbangun secara fakta marak terjadi pada kawasan daerah aliran sungai Maros. Kawasan daerah aliran sungai yang terbanguni berpotensi menyebabkan gangguan ekologis dan hidrologis yang berdampak pada terjadinya banjir karena berkurangnya lahan resapan air serta berubahnya morfologi daerah aliran sungai. Tujuan pertama penelitan ini adalah mengetahui kondisi penggunaan lahan terbangun serta perubahannya dalam kurung waktu 5 tahun terakhir di kawasan Daerah Aliran Sungai Maros menggunakan metode analisi tumpang tindih peta. Tujuan kedua adalah mengkaji pengaruh perubahan penggunaan lahan terbangun terhadap banjir di kawasan Daerah Aliran Sungai Maros dengan menggunakan analisis regresi linear sederhana. Variabel prediktor yang digunakan yaitu perubahan penggunaan lahan (X), dengan variabel kriterium adalah luas banjir (Y). Hasil penelitian menunjukkan bahwa perubahan penggunaan lahan terbangun pada kawasan daerah aliran sungai Maros mengalami peningkatan yang cukup tinggi, dimana lahan kebun yang berubah menjadi permukiman sebesar 18,4 ha. Sedangkan sawah yang berubah menjadi permukiman sebesar 3,68 ha dari tahun 2015 ke tahun 2019. Perubahan penggunaan lahan terbangun yang terjadi berpengaruh kuat dan signifikan terhadap peningkatan luas genangan banjir pada kawasan daerah aliran sungai Maros.
\end{abstract}

Kata Kunci: Perubahan Penggunaan Lahan, Daerah Aliran Sungai, Sistem Informasi Geografis, Maros

Abstract. The urban area in Maros Regency is traversed by the Maros River. Maros River flows towards Makassar Strait and is the mouth of other rivers in upstream. Maros River which passes through the urban area has a watershed river that is vulnerable to conversion. The growth of conversion of non-built land into built-up areas in fact is rife in Watershed Maros. Developed watershed areas have the potential to cause ecological and hydrological disturbances that have an impact on flooding due to reduced water catchment areas and changing morphology of river basins. The first objective of this research is to determine the conditions of built-up areas and changes within the last 5 years in the Watershed Maros using overlapping map analysis method. The second purpose is to examine the effect of changes in built-up land use on flooding in Maros watershed area using simple linear regression analysis. The predictor variables used are land use change $(X)$, with the criterion variable is the flood area $(Y)$. The results showed that the land use change was built on the watershed area of Maros has increased quite highly, where 18.4 ha of land has been converted into a settlement. While the rice fields are changed to a settlement of 3.68 ha from 2015 to 2019. Changes on the use of built-up land that occurs have a strong and significant effect on increasing the area of flood inundation in the watershed area of Maros

Keywords: Land Use Change, Watershed, Geographic Information System, Maros

\section{Pendahuluan}

Pembangunan wilayah merupakan bagian integral dari pembangunan Nasional yang bertujuan untuk meningkatkan taraf hidup dan kesejahteraan masyarakat. Pembangunan tersebut akan dilaksanakan secara serasi, selaras, dan seimbang di wilayah perkotaan dan pedesaan.

Dalam konsep pengembangan kawasan telah banyak dikemukakan untuk menjelaskan persoalan-persoalan ketidakseimbangan dalam pembangunan wilayah, beberapa persoalan penting berkaitan dengan peran pusat dalam pembangunan wilayah yang harus diberikan perhatian penting, yaitu mengenai penentuan berapa jumlah sampul utama yang tepat difungsikan sebagai pusat-pusat wilayah pembangunan, hirarki kota, hubungan fungsional antar sampul yaitu kearah mana orientasi didistribusikan secara geografis tiap-tiap sampul dilakukan.

Dalam Rangka percepatan pelaksanaan pembangunan dan pelayanan terhadap masyarakat dapat ditinjau dan melihat pola perkembangan penggunaan lahan di kawasan daerah aliran sungai Maros. Penataan ini dilakukan dengan suatu pertimbangan terhadap kondisi dan kebutuhan yang nyata pada wilayah tersebut. Kebutuhan akan lahan yang terus meningkat perlu diatur dalam perencanaan wilayah demi terciptanya keseimbangan tata ruang yang baik dan berkelanjutan. Peruntukan lahan di setiap wilayah haruslah 
diikuti dengan kebutuhan yang seimbang agar kelestarian alam tetap terjaga dengan pola pemenuhan kebutuhan manusia.

Lahan merupakan bagian dari bentang alam (landscape) yang mencakup pengertian lingkungan fisik termasuk iklim, topografi/relief, hidrologi termasuk keadaan vegetasi alami yang semuanya secara potensial akan berpengaruh terhadap penggunaan lahan (Sitorus 2004). Pengertian tentang penutupan dan penggunaan lahan penting untuk berbagai kegiatan perencanaan dan pengelolaan yang berhubungan dengan permukaan bumi. Penutupan lahan berkaitan dengan jenis kenampakan yang ada di permukaan bumi, sedangkan penggunaan lahan berkaitan dengan kegiatan manusia pada bidang lahan tertentu (Lillesand \& Kiefer 1997).

Alokasi pemanfaatan ruang dalam bentuk tata guna lahan merupakan suatu pengaturan dan pemanfaatan lahan untuk berbagai kegiatan dengan fungsi yang telah ditetapkan disetiap kawasan dengan sasaran yang ingin dicapai adalah penggunaan dan pemanfaatan lahan secara optimal untuk memperoleh hasil yang optimal tanpa memberikan dampak lingkungan. Perunahan fungsi lahan atau pergeseran fungsi lahan adalah lahan yang mengalami peralihan pemanfaatan misalnya lahan non terbangun menjadi lahan terbangun yang disebabkan oleh perubahan pola pemanfaatan lahan, 8 faktor lain yang mempengaruhi ialah sarana dan prasarana terhadap perkembangan kawasan. Perubahan penggunaan lahan dari lahan non terbangun menjadi terbangun seperti dari tegalan atau pekarangan menjadi permukiman, perkantoran atau industri akan menyebabkan berkurangnya kemampuan lahan untuk meresapkan air hujan (Surya et al. 2020; Buraerah et al., 2020).

Dalam pengelolaannya peruntukan lahan tidak bisa dikelola dengan hanya melihat pembagian menurut wilayah administrasi saja, salah satu contoh pada pembangunan jalan mengakibatkan bangkitan permukiman dan penggunaan lahan lainnya (Mokoginta et al, 2021), ini akan menyebabkan kerugian pada wilayah lainnya. Sebagai contoh: di suatu daerah tertentu masyarakat yang melakukan budidaya pada lahan-lahan yang mempunyai kelerengan yang cukup tinggi tanpa melakukan teknik konservasi, dapat mengakibatkan lahan menjadi rusak di daerah hulu, dan mengakibatkan banjir di daerah hilir. Untuk itu perlu dilakukan dengan pendekatan Daerah Aliran Sungai (Ariandi et al., 2020).

Daerah Aliran Sungai (DAS) adalah suatu wilayah daratan yang secara topografik dibatasi oleh punggungpunggung gunung yang menampung dan menyimpan air hujan untuk kemudian menyalurkannya ke laut melalui sungai utama. Wilayah daratan tersebut dinamakan daerah tangkapan air (DTA atau catchment area) yang merupakan suatu ekosistem dengan unsur utamanya terdiri atas sumberdaya alam (tanah, air, dan vegetasi) dan sumberdaya manusia sebagai pemanfaat sumberdaya alam (Asdak 2004). Lee (1998) mengatakan bahwa daerah tangkapan air meliputi semua titik yang terletak di atas elevasi (ketinggian tempat) stasiun penakar dan di dalam batas topografi atau igir (topographic divide) yang memisahkan daerah-daerah tangkapan beragam cukup besar dengan komposisi dan struktur lapisan batuan di bawahnya.

Menurut Undang-Undang Nomor 7 Tahun 2004, disebutkan bahwa Daerah Aliran Sungai adalah suatu wilayah daratan sebagai satu kesatuan dengan sungai dan anak-anak sungai yang berfungsi untuk menampung, menyimpan, dan mengalirkan air yang berasal dari curah hujan ke danau atau ke laut secara alami. Sedangkan batas di darat merupakan pemisah topografis dan batas di laut sampai dengan daerah 9 perairan yang masih terpengaruh oleh aktivitas daratan. Daerah Aliran Sungai (DAS) merupakan kesatuan wilayah bersifat kompleks yang dipengaruhi oleh karakteristik fisik variabel meteorologinya. Karakteristik fisik yang berupa pola penggunaan lahan, bentuk jaringan sungai, kondisi tanah, topografi, dan ketinggian tempat merupakan karakteristik DAS yang sifatnya dapat dipengaruhi oleh kegiatan manusia. Sedangkan variabel meteorologi yang meliputi curah hujan, suhu, kelembaban, radiasi matahari, dan kecepatan angin bersifat sangat berubah-ubah tergantung kondisi klimatnya (Dewan Riset Nasional Kelompok II, Sumberdaya Alam dan Energi 1994).

Daerah Aliran Sungai (DAS) yang berada di Kabupaten Maros adalah DAS Maros. Kabupaten Maros merupakan wilayah yang menarik, ini dikarenakan Kabupaten Maros dengan peruntukan lahan yang kompleks diapit 2 Daerah Aliran Sungai (DAS) besar yaitu DAS Tallo dan DAS Minraleng data diperoleh dari dinas PSDA Provinsi Sulawesi Selatan.

Bentuk bentang alam menonjol terjadi sekitar hulu DAS Maros, membentuk kerucut Gunung api Lompobattang mencapai ketinggian 2.876 mdpl, terbentuk oleh batuan gunung api semasa Plistosen (Sukamto \& Supriatna, 1982). Bagian hilir DAS Maros terbentuk menjadi daerah dataran rendah pesisir pantai barat Sulawesi Selatan, sebagian besar berupa daerah rawa dan pasang surut, dimana kawasan ini telah menjadi kawasan dataran banjir. Luas DAS Maros kurang lebih 672,24 km2 dan panjang sungai utama adalah $65 \mathrm{~km}$. Aliran Sungai mengalir menuju Selat Makassar dan merupakan muara bagi sungai-sungai lain di bagian hulu.

Sungai Maros saat ini banyak dimanfaatkan oleh masyarakat di Kabupaten Maros untuk pertanian (Syafri et al., 2019), lalu lintas kapal nelayan menuju ke laut, dan aktifitas hilir mudik kapal nelayan ke Tempat Pelelangan Ikan (TPI) yang terletak di Desa Pettuadae Kecamatan Turikale serta kegiatan lainnya.

Seringnya Sungai Maros digunakan untuk aktifitas lalu lintas kapal nelayan menuju ke laut dan aktifitas hilir mudik kapal nelayan ke Tempat Pelelangan Ikan (TPI), Penambangan Pasir dan aktifitas lainnya menyebabkan pada beberapa titik terdapat batas sempadan sungai yang sudah tidak sesuai peraturan hal ini terkadang menyebabkan terjadinya banjir dan longsor pada saat terjadi banjir besar.

Perencanaan tata ruang harus mempertimbangkan daerah hulu dan daerah hilir DAS, terkait peruntukan lahan maka perencanaan peruntukan lahan haruslah meliputi seluruh DAS. Dalam hubungannya dengan perencanaan pembangunan wilayah, penelitian ini mempunyai kaitan yang sangat erat di mana pola pemanfaatan lahan akan mempengaruhi kelangsungan dan kelestarian DAS. Pemanfaatan lahan terbangun pada wilayah DAS secara langsung akan mengurangi daerah resapan air dan merubah morfologi DAS, sehingga dapat berdampak pada timbulnya banjir pada welayah tersebut.

Kebutuhan manusia akan lahan terus meningkat, baik kebutuhan akan tempat tinggal, tempat usaha, fasilitas umum, sarana dan prasarana. Oleh karena itu banyak 
peraturan yang mengatur tentang pemanfaatan lahan/tata guna lahan dan tata ruang wilayah agar pola pemanfaatannya tidak merusak ekosistem yang ada. Wilayah yang diteliti adalah Daerah Aliran Sungai Maros dengan ruang permasalahan yang kompleks, ini akan di review dari data yang tersedia di instansi pemerintah yang berwenang, apakah penggunaan dan pemanfaatan lahan selama ini telah sesuai dengan rencana yang sudah ditetapkan (regulasi). Analisa penelitian ini menggunakan sistem informasi geografis perangkat lunak arcGIS dan penginderaan jauh. Dari hasil analisa tersebut diharapkan mempunyai solusi dari penyimpangan peruntukan lahan dari yang telah ditetapkan, salah satunya dengan cara membuat data ketersediaan lahan untuk perencanaan kedepan demi kelestarian ekosistem daerah aliran sungai Maros.

Mengingat pentingnya peruntukan lahan untuk kehidupan maka perlu diteliti pemanfaatan lahan, fungsi lindung, komparasi faktual penutupan lahan dengan peruntukan seharusnya, serta perencanaan tata ruang. Dengan demikian dari hasil penelitian ini diharapkan dapat memberikan arahan fungsi dan tata guna lahan demi kelestarian lingkungan dan terjaganya ekosistem DAS. Hal ini yang menjadi dasar peneliti mengangkat penelitian tentang "Pengaruh Perubahan Penggunaan Lahan Terbangun Terhadap Banjir di Kawasan Daerah Aliran Sungai Maros".

\section{Metode Penelitian}

a) Jenis Penelitian

Jenis penelitian ini menggunakan pendekatan deskriptif kuantitatif dengan tujuan untuk menggambarkan data yang terkumpul secara sistematis, cermat dan akurat mengenai fenomena tertentu berupa fakta-fakta, keadaan, sifat-sifat suatu individu atau kelompok, serta hubungan antara fenomena yang diselidiki (Singarimbun dan Effendi, 1989). Kegiatan yang dilakukan adalah mengidentifikasi kondisi eksisting, penggunaan lahan, perubahan penggunaan lahan serta faktor yang mempengaruhinya. Berbagai data yang diperoleh untuk dilakukan analisis sehingga dapat menghasilkan suatu gambaran dinamika perubahan penggunaan lahan serta faktor yang mempengaruhi pengunaan lahan kawasan Daerah Aliran Sungai. Desain penelitian yang dilakukan adalah dengan metoda matematis, bertujuan untuk memperoleh data dan informasi yang lebih akurat.

b) Lokasi Penelitian

Lokasi penelitian ini berada di Daerah Aliran Sungai Maros terbentang dari timur ke barat terletak pada 4058'2,96" -5012'53,05" Lintang Selatan dan 119o28'31,02" - 119047'54,8”. Sedangkan berdasarkan Administrasi Sungai Maros sendiri dalam penelitian ini terletak di Kecamatan Simbang yang terdiri dari Desa Bonto Tallasa dan Desa Tanete, serta Kecamatan Turikale yakni di Desa Pettuadae dan Desa Bori Bellaya, Kabupaten Maros

\section{c. Lingkup Penelitian}

Peneliti menyadari sepenuhnya bahwa dalam penelitian ini terdapat keterbatasan waktu serta kemampuan, maka peneliti memandang perlu adanya batasan lingkup penelitian agar pengkajiannya lebih fokus dan jelas. Batasan yang dimaksud adalah :

a. Lingkup Wilayah (Spasial); Daerah Aliran Sungai Maros yang menjadi lokasi penelitian mencakup lahan seluas 534,77 km2 dan Panjang sungai 9,2 Kilometer Sedangkan berdasarkan Administrasi Sungai Maros mencakup 2 Kecamatan yaitu, Kecamatan Simbang Desa Bonto Tallasa dan Desa Tanete sedangkan Kecamatan Turikale, Desa Pettuadae dan Desa Bori Bellaya.

b. Lingkup Materi (Substansial); terbatas pada kajian untuk mengetahui kondisi perubahan penggunaan lahan terbangun dalam kurung waktu 5 tahun terakhir, serta mengkaji pengaruh perubahan penggunaan lahan terbangun tersebut terhadap intensitas banjir yang terjadi.

d. Variabel Penelitian

Variabel penelitiaan pada dasarnya adalah segala sesuatu yang berbentuk apa saja yang ditetapkan oleh peneliti untuk dipelajari sehingga diperoleh informasi tentang hal tersebut, kemudian ditarik kesimpulannya (Sugiyono, 2012). Secara teoritis variabel dapat didefenisikan sebagai atribut seseorang, atau obyek, yang mempunyai "variasi" antara satu orang dengan orang yang lain atau suatu obyek dengan obyek yang lain (Hatch dan Farhady, 1981 dalam Sugiyono, 2012). Sugiyono (2012), dalam bukunya Metode Penelitiaan Kombinasi menyebutkan, variabel penelitian adalah suatu atribut atau sifat atau nilai dari orang, obek atau kegiatan yang mempunyai variasi tertentu yang ditetapkan oleh peneliti untuk dipelajari dan kemudian ditarik kesimpulannya. Penggunaan jenis variabel sangat tergantung pada jenis rumusan masalah dalam sebuah penelitiaan. Untuk menjawab rumusan masalah maka variabel sesuai pembahasan adalah Perubahan Penggunaan Lahan dan Luas dan Tiinggi Genangan Banjir.

e. Populasi dan Sampel

Populasi adalah wilayah generalisasi yang terdiri dari obyek/subyek yang mempunyai kualitas dan karakteristik tertentu yang ditetapkan untuk dipelajari dan ditarik kesimpulan. Adapun polulasi penelitian ini adalah masyarakat yang bermukim pada lokasi penelitian yakni pada kawasan daerah aliran sungai Maros.

Sampel menurut Arikunto (2013), sampel merupakan bagian atau wakil populasi yang diteliti. Bila populasi lebih dari 100, maka besarnya sampel dapat ditentukan 10-15\% atau 20-25\%. Dalam penelitian ini, wakil atau bagian dari populasi yang menjadi responden adalah pengguna ruang publik, menurut Sudjana $(2001 ; 165)$, bahwa sampel yang mempunyai populasi yang heterogen, maka besaran sampel antara $15-20 \%$ dari jumlah populasi. Sedangkan menurut Sugiyono $(2004 ; 65)$ apabila populasi bersifat homogen, maka jumlah sampel yang diperlukan $1 \%$ saja sudah mewakili. Untuk mengefisiensi penelitian, maka sampel ditetapkan secara proporsional dengan menggunakan rumus matematis;

$$
n=\frac{N}{N(d)^{2}+1}
$$

Dimana ;

$\mathrm{n}:$ Jumlah sampel yang diambil 
$\mathrm{N}$ : Jumlah mata pencaharian dan pendapatan masyarakat D : Derajat Kebebasan $(15-20 \%)$

\section{f. Jenis dan Sumber Data}

Jenis data pada penelitian inia adalah data kuantitatif dan data kualitatif. Jenis data kuantitatif seperti data luas wilayah penelitian; data luas kawasan penelitian; data demografi, dan lainnya. Sedangkan yang masuk dalam jenis data kualitatif seperti kondisi fisik kawasan penelitian; kondisi penggunaan lahan, dan lainnya Sumber data yang dikumpulkan dalam penelitian ini adalah data primer dan data sekunder. Data primer merupakan data yang diperoleh langsung dari lapangan (ground check), meliputi: kondisi penggunaan lahan pada masa sekarang, foto dokumentasi, koordinat hasil survey lapangan, pengecekan kebenaran data, sebaran pemukiman dan jalan dan pemetaan lokasi, sedangkan data sekunder merupakan data yang diperoleh dari Instansi Pemerintah yang terkait dengan penelitian ini, meliputi: peta dan data yang tersedia sebagai alat bantu penelitian, dalam bentuk laporan instansi (Bappeda, Dinas Pekerjaan Umum dan Dinas Kehutanan), data statistik (Kantor Pusat Statistik BPS), data Daerah Aliran Sungai Sulawesi Selatan (Balai Pengelolaan Daerah Aliran Sungai Pompengan-Jeneberang), data curah hujan, data peruntukan lahan (ATR/BPN), data lingkungan, data rencana tata ruang wilayah Kabupaten 21 Maros, data tata guna hutan kesepakatan (Badan Planologi Kehutanan) dan data informasi pendukung lainnya yang berkaitan dengan penggunaan lahan

\section{g. Teknik Pengumpulan Data}

a) Survei merupakan suatu penelitian kuantitatif dengan menggunakan pertanyaan terstruktur/sistematis yang sama kepada banyak orang, untuk kemudian seluruh jawaban yang diperoleh peneliti dicatat, diolah, dan dianalisis. Dalam metode survei, kuesioner adalah instrumen utama untuk mengumpulkan data (Soehartono, 2006, hal. 109). Kuesioner merupakan daftar pertanyaan tertulis, yang sekaligus akan mencatat jawaban dari responden (Nasution, 2006, hal. 98). Pada metode survei juga dapat dilakukan pengambilan data berupa dokumentasi visual menggunakan kamera berupa gambar ataupun video.

b) Observasi atau pengamatan merupakan salah satu teknik pengumpulan data/fakta yang cukup efektif untuk mempelajari suatu sistem. Penggunaan teknik ini dilakukan oleh peneliti untuk tujuan mengamati kondisi dan sistem kerja di Unit Pengolahan Sampah (UPS) di tiap-tiap Kecamatan . Melalui observasi ini, peneliti akan menganalisis dan membandingkan hasil wawancara maupun survei dengan fakta-fakta di lapangan.

c) Penelitian ini juga didukung oleh data-data sekunder yang berkaitan dengan permasalahan terkait penelitian ini, yang terdiri buku literatur, artikel ilmiah, hasil penelitian, dokumen-dokumen persempahan, dan peraturan perundang-undangan.

h. Teknik Analisis Data

a) Metode Deskriptif

Analisis deskriptif digunakan untuk menganalisa data dengan menggambarkan keadaan wilayah pengamatan sesuai data yang diperoleh, kemudian mengklasifikasi berdasarkan tujuan yang dicapai. Untuk mengevaluasi varieabel-variabel yang dinyatakan dengan sebuah frekuensi, berupa angka mutlak dan presentase digunakan teknik deskriptif kualitatif. Analisis deskriptif ini akan memperkuat dan saling berkaitan dengan hasil analisis melalui teknik overlay peta pada analisis spasial.

b) Metode Tumpang Tindih Peta (Overlay)

Metode yang digunakan dalam penelitian ini adalah metode Overlay (tumpang tindih) dan Analizing Spasial dengan menggunakan teknologi Informasi Geografi perangkat lunak ArcGIS. Pengolahan data dilakukan untuk menentukan pola penggunaan lahan (data land use), mengetahui curah hujan (data BMG), kemiringan (data topografi), penutupan lahan (vegetasi), fungsi lindung dan fungsi budidaya (data RTRW Kabupaten Maros), jumlah penduduk tersebar (data BPS), Foto udara/Aerial Mapping, data survey ke lapangan di daerah DAS Maros. Data berupa peta yang berisi informasi dianalisis melalui teknik overlay/tumpang tindih layer (lembar) untuk mendapatkan data perbandingan dan data gabungan, teknik ini dilakukan menggunakan perangkat lunak software ArcGIS.

\section{Hasil dan Pembahasan}

1. Perubahan Penggunaan Lahan Terbangun di Kawasan daerah Aliran Sungai Maros

a. Analisis Perubahan Penggunaan Lahan Terbangun Di Kawasan Daerah Aliran Sungai Maros Kurun Waktu 5 Tahun Terakhir Menggunakan Metode Overlay

Analisis perubahan penggunaan lahan terbangun pada kawasan penelitian perlu dilakukan untuk mengetahui seberapa besar perubahan penggunaan lahan terbangun yang terjadi selama 5 tahun terakhir. Analisi ini diproses pada perangkat lunak ArsGIS dengan menggunakan metode overlay/tumpang tindih peta. Overlay merupakan proses penyatuan data dari lapisan layer yang berbeda. Secara sederhana overlay disebut sebagai operasi visual yang membutuhkan lebih dari satu layer untuk digabungkan secara fisik.

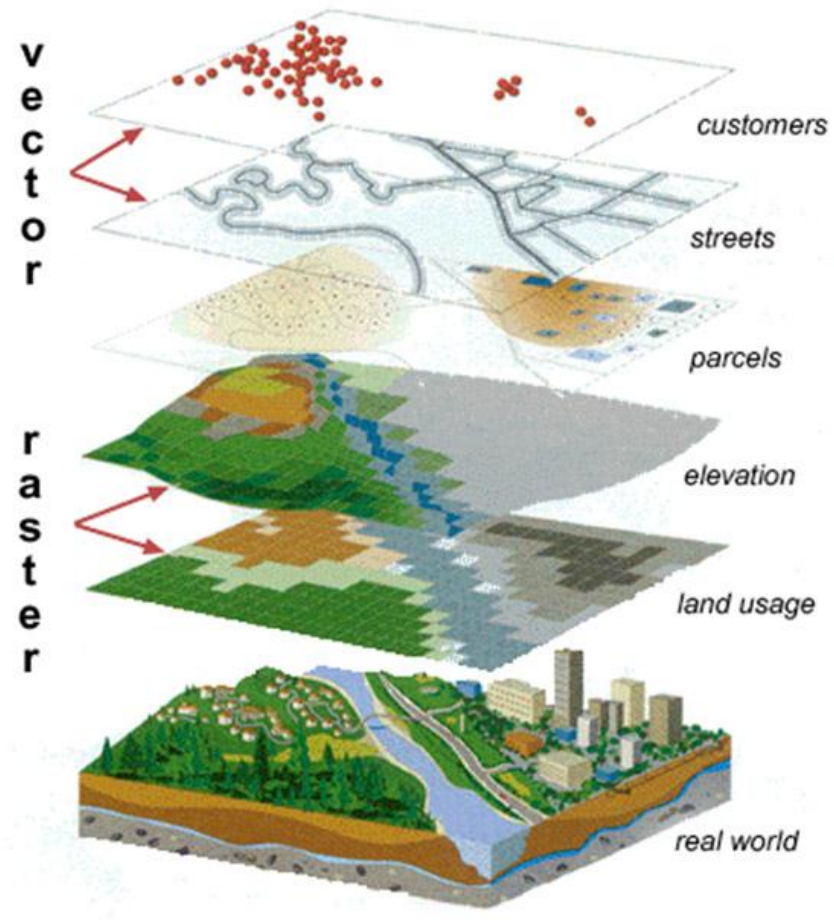

Gambar 1 Ilustrasi Teknik Overlay pada SIG 
Pemahaman bahwa overlay peta (minimal 2 peta) harus menghasilkan peta baru adalah hal mutlak. Dalam bahasa teknis harus ada poligon yang terbentuk dari 2 peta yang di-overlay. Jika dilihat data atributnya, maka akan terdiri dari informasi peta pembentuknya. Pada proses analisis ini, peta yang digunakan terdiri dari peta penggunaan lahan tahun 2015 dan peta penggunaan lahan tahun 2019. Kedua peta tersebut di-overlay untuk melihat perubahan penggunaan lahan terbangun yang terjadi dari tahun 2015 ke tahun 2019.

Tabel 1 Luas Perubahan Penggunaan Lahan di Wilayah Penelitian Tahun 2015-2019

\begin{tabular}{ccccc}
\hline \multirow{2}{*}{ No. } & \multicolumn{2}{c}{ Jenis Penggunaan Lahan } & Luas (ha) & Keterangan \\
\cline { 2 - 3 } & $\mathbf{2 0 1 5}$ & $\mathbf{2 0 1 9}$ & & \\
\hline 1 & Kebun & Kebun & 172,98 & Tidak berubah \\
2 & Kebun & Lahan Kosong & 0,92 & Berubah \\
3 & Kebun & Permukiman & 18,4 & Berubah \\
4 & Kebun & Sawah & 2,11 & Berubah \\
5 & Permukiman & Kebun & 12,15 & Berubah \\
6 & Permukiman & Lahan Kosong & 0,29 & Berubah \\
7 & Permukiman & Permukiman & 50,59 & Tidak berubah \\
8 & Sawah & Kebun & 5,44 & Berubah \\
9 & Sawah & Permukiman & 3,68 & Berubah \\
10 & Sawah & Sawah & 55,21 & Tidak berubah \\
11 & Sungai & Sungai & 39,84 & Tidak berubah \\
\hline Sumber $:$ Hasil Analisis Overlay Penggunan Lahan Tahun $2015 \&$ 2019
\end{tabular}

Berdasarkan data hasil overlay pada tabel 4.16 diatas, terlihat bahwa perubahan jenis lahan non terbangun menjadi lahan terbangun paling besar adalah lahan kebun yang berubah menjadi permukiman yakni mengalami bertambah dari tahun 2015 ke tahun 2019 sebesar 18,4 ha. Sedangkan jenis penggunaan lahan berupa sawah yang berubah menjadi permukiman sebesar 3,68 ha.

Perubahan penggunaan lahan terbangun menjadi non terbangun paling besar adalah dari lahan permukiman pada tahun 2015 menjadi kebun pada tahun 2019 sebesar 12,15 ha. Sementara lahan permukiman yang berubah menjadi lahan kosong sebesar 0,29 ha. Lahan terbangun berupa permukiman yang tidak mengalami perubahan dari tahun 2015 hingga tahun 2019 adalah seluas 50,59 ha atau sekitar 13,99\% dari luas wilayah penelitian

b. Pembahasan Hasil Analisis Perubahan Penggunaan Lahan Terbangun Di Kawasan Daerah Aliran Sungai Maros Kurun Waktu 5 Tahun Terakhir〉

Perubahan lahan yang terjadi pada lokasi penelitian didominasi oleh konversi lahan non terbangun menjadi lahan terbangun. Lahan yang sebelumnya merupakan kebun berubah menjadi pemukiman seluas 18,4 ha, sedangkan persawahan berubah menjadi permukiman sebesar 3,68 ha.

Perubahan penggunaan lahan dari lahan non terbangun menjadi terbangun seperti dari kebun atau sawah menjadi permukiman, perkantoran atau perdagangan akan menyebabkan berkurangnya kemampuan lahan untuk meresapkan air hujan. Hal ini terjadi karena berkurangnya lahan resapan air akibat betonisasi lahan terbangun.

Pertumbuhan lahan permukiman yang terjadi pada lokasi penelitian seiring dengan pertumbuhan penduduk yang terjadi. Dalam kurun waktu 5 tahun terakhir, laju pertumbuhan penduduk pada lokasi penelitian mencapai $3,62 \%$. Pertumbuhan penduduk yang terjadi berbanding lurus dengan kebutuan akan lahan tempat tinggal. Selain itu, kebutuhan lahan lainnya seperti perkantoran, perdagangan, dan industri juga mengalami peningkatan.

Undang-undang nomor 26 tahun 2007 tentang penataan ruang mengisyaratkan ruang terbuka hijau yang salah satu fungsinya sebagai lahan resapan 0- minimal $30 \%$ untuk publik dan $10 \%$ untuk privat. Hal tersebut bertujuan untuk menjaga keberlangsungan ekosistem didalamnya, terutama memelihara sumberdaya air tanah dan mencegah terjadinya genangan atau banjir permukaan.

2. Pengaruh Perubahan Penggunaan Lahan Terhadap Banjir di Kawasan Aliran Sungai Maros

Analisis ini bertujuan untuk mengetahui pengaruh antara variabel independen (X) terhadap variabel dependen (Y). Koefisien ini menunjukkan seberapa signifikan pengaruh yang terjadi antara variabel perubahaan penggunaan lahan $(\mathrm{X})$ terhadap variabel luas banjir $(\mathrm{Y})$.

a. Analisis Pengaruh Perubahan Penggunaan Lahan

Terhadap Banjir Di Kawasan Daerah Aliran Sungai Maros

Analisis dengan metode regresi sederhan ini dilakukan untuk mengukur luas banjir menggunakan variabel bebas perubahan penggunaan lahan terbangun. Analisis ini menggunakan alat bantu aplikasi SPSS 22.0. Dimana data yang digunakan berupa data time series luas banjir dan perubahan penggunaan lahan terbangun selama tahun 2015 sampai 2019, yang dimasukkan ke aplikasi SPSS 22.0 kemudian dianalisis dengan alat regresi linear menggunakan metode enter. Hasil atau luaran dari proses analisis tersebut berbentuk tabulasi (lihat lampiran 2) yang disajikan kedalam pembahasan ini kemudian diinterpretasikan untuk menemukan dan menjelaskan hasil dari angka-angka tersebut ke dalam deskripsi kalimat agar lebih mudah untuk dipahami.

Koefisien Persamaan Regresi dapat disusun dengan melihat nilai output yang dihasilkan melalui pengujian Regresi bahwa nilai pada kolom (Unstandardized Coefficients-B) diatas, maka dapat disusun persamaan regresinya dengan rumus matematis sebagai berikut :

Maka didapat persamaan :

$$
\mathrm{Y}=\mathrm{a}+\beta \mathrm{X}
$$

$$
\mathrm{Y}=-1022.487+16.578
$$

Persamaan regresi di atas dapat dijelaskan sebagai berikut:

- Konstanta sebesar -1022,487; artinya jika perubahan penggunaan lahan (X) nilainya tetap atau sama dengan nol, maka besarnya penurunan luas banjir (Y) nilainya adalah 1022,487.

- Koefisien regresi variabel perubahan penggunaan lahan (X) sebesar 16,578; artinya jika variabel perubahan penggunaan lahan mengalami kenaikan $1 \%$, maka luas banjir (Y) akan mengalami peningkatan sebesar 16,578 . Koefisien bernilai positif artinya terjadi hubungan positif antara perubahan penggunaan lahan dengan luas banjir, semakin meningkat perubahan penggunaan lahan maka semakin bertambah luas banjir.

Uji $\mathrm{t}$ (uji parsial) ini dilakukan untuk mengetahui apakah variabel perubahan penggunaan lahan (X) berpengaruh secara signifikan terhadap variabel luas banjir (Y). Signifikan berarti hubungan yang terjadi dapat berlaku 
untuk populasi (dapat digeneralisasikan). Uji t dilakukan dengan terlebih dahulu menentukan nilai-nilai berikut ini :

- Menentukan Taraf Signifikansi

Taraf signifikansi menggunakan $\alpha=10 \%$ (signifikansi $10 \%$ atau 0,1 adalah ukuran yang sering digunakan dalam penelitian dengan populasi yang besar).

- Merumuskan Hipotesis

Rumusan hipotesis berdasarkan pendekatan teoritis seperti yang telah dibahas pada bab II adalah sebagai berikut :

$\mathrm{Ha}$ : Perubahan penggunaan lahan berpengaruh secara signifikan terhadap luas banjir pada kawasan daerah aliran sungai Maros.

- Menentukan $T_{\text {tabel }}$

Dengan menggunakan tingkat keyakinan $90 \%, \alpha=$ $10 \%$ atau 0,1 , nilai df residual (n-k-1) atau $100-4-1=$ 95 ( $\mathrm{n}$ adalah jumlah data dan $\mathrm{k}$ adalah jumlah variabel prediktor).

Untuk menghitung nilai ttabel menggunakan bantuan excel dengan memasukkan rumus sebagai berikut :

\section{=TNV(probability; deg_freedom)}

Keterangan :

- probability : probabilitas $(0,10)$

- deg_freedom : derajat kebebasan (95)

- $\quad$ Menentukan Thitung

Berdasarkan hasil analisis diperoleh thitung sebesar 8,461

- Kriterian Pengujian

Ha terima jika Thitung $>$ Ttabel

Ha ditolak jika Thitung < Ttabel

- Membandingkan Thitung dan Ttabel

Nilai thitung > ttabel $(8,461>1,291)$, maka $\mathrm{Ha}$ diterima.

\section{- Kesimpulan}

Karena thitung > ttabel $(8,461>1,291)$, maka Ha diterima. Artinya, pada perhitungan ini dapat disimpulkan bahwa perubahan penggunaan lahan berpengaruh signifikan terhadap luas banjir pada kawasan daerah aliran sungai Maros.

Koefisien korelasi dalam regresi linear berganda digunakan untuk mengetahui hubungan antara variabel prediktor perubahan penggunaan lahan $(\mathrm{X})$ berpengaruh terhadap variabel luas banjir $(\mathrm{Y})$. Koefisien ini menunjukkan seberapa besar hubungan yang terjadi antara variabel prediktor $(\mathrm{X})$ secara terhadap variabel kriterium (Y). Nilai $\mathrm{R}$ berkisar antara 0 sampai 1 , nilai semakin mendekati 1 berarti hubungan yang terjadi semakin kuat, sebaliknya nilai semakin mendekati 0 maka hubungan yang terjadi semakin lemah.

Menurut Usman dan Purnomo (2011 : 201) pedoman untuk memberikan interpretasi koefisien korelasi sebagai berikut :

$\mathrm{Kk}=0$, tidak berkorelasi

$\mathrm{Kk}=0,001-0,200$, korelasi sangat rendah/lemah

$\mathrm{Kk}=0,201-0,400$, korelasi rendah/lemah

$\mathrm{Kk}=0,401-0,600$, korelasi agak rendah/lemah

$\mathrm{Kk}=0,601-0,800$, korelasi cukup tinggi/kuat

$\mathrm{Kk}=0,801-0,999$, korelasi tinggi/kuat

$\mathrm{Kk}=1$, korelasi sangat tinggi/kuat, sempurna.

Dari hasil analisis koefisien regresi pada tabel 4.17 diatas, dalam kolom (Correlations-Partial) diperoleh angka $\mathrm{R}$ untuk variabel perubahan penggunaan lahan sebesar 0,980 . Nilai tersebut menunjukkan bahwa terjadi hubungan yang kuat antara perubahan penggunaan lahan $(\mathrm{X})$ terhadap luas banjir (Y). Angka positif (searah) mengartikan bahwa jika perubahan penggunaan lahan maka luas banjir juga akan mengalami peningkatan.

b. Pembahasan Hasil Analisis Pengaruh Perubahan

Penggunaan Lahan Terhadap Banjir di Kawasan

Daerah Aliran Sungai Maros

Meningkatnya penggunaan lahan terbangun secara langsung menyebabkan penutupan lahan permukaan yang relatif kedap air (betonisasi lahan). Berkurangnya resapan air akibat pengguaan lahan terbangun ini sebaliknya akan meningkatkan limpasan permukaan yang selanjutnya memperbesar peluang terjadinya banjir.
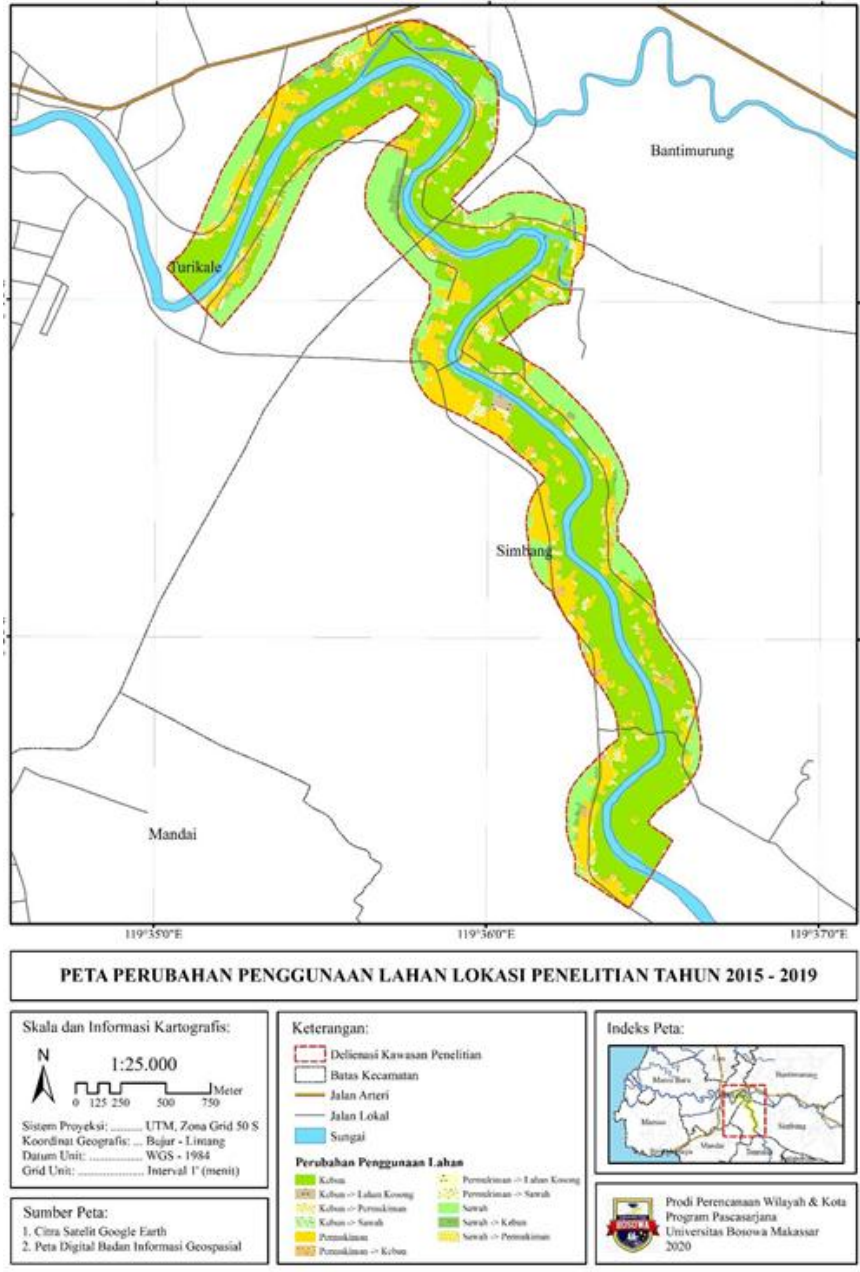

Gambar 2 Peta Perubahan Penggunaan Lahan Lokasi Penelitian Tahun 2015 - 2019

Woube (1999), banjir terjadi karena perubahan dan pengelolaan penggunaan lahan yang tidak tepat. Sedangkan Kodoatie dan Syarief (2006) menjelaskan faktor penyebab banjir antara lain perubahan guna lahan, pembuangan sampah, erosi dan sedimentasi, kawasan kumuh di sepanjang sungai, sistem pengendalian banjir yang tidak tepat, curah hujan tinggi, fisiografi sungai, kapasitas sungai yang tidak memadai, pengaruh air pasang, penurunan tanah, bangunan air, kerusakan bangunan pengendali banjir. Diantara berbagai faktor penyebab terjadinya banjir tersebut diatas, faktor perubahan guna lahan atau tata ruang merupakan penyebab utama terjadinya banjir di banyak daerah.

Berdasarkan pertimbangan dari berbagai faktor yang telah disebutkan para ahli diatas, maka dirumuskanlah faktor yang dianggap mewakili dalam mengukur pengaruh signifikan dari meningkatnya luas genangan banjir pada 
kawasan penelitian daerah aliran sungai Maros. Faktor yang kemudian menjadi variabel tersebut adalah perubahan penggunaan lahan terbangun.

Faktor penggunaan lahan terbangun diuraikan berdasarkan waktu (time series), yakni dari tahun 2015 sampai tahun 2019. Dengan diproses menggunakan analisi regresi linear sederhana seperti yang telah dilakukan pada pembahasan sebelumnya, variabel penggunaan lahan terbangun tersebut dinyatakan memiliki pengaruh signifikan terhadap meningkatnya luas genangan banjir pada kawasan penelitian daerah aliran sungai Maros.

Hasil analisi membuktikan bahwa penggunaan lahan terbangun berpengaruh kuat dan signifikan terhadap peningkatan luas genangan banjir pada lokasi penelitia. Hal ini sejalan dengan berbagai teori dan pengamatan lapangan dimana peningkatnya penggunaan lahan terbangun seperti permukiman, industri, pertokoan dan lainnya berdampak pada berkurangya lahan resapan air pada kawasan daerah aliran sungai Maros. Lahan resapan air yang berkurang mengakibatkan aliran limpasan air hujan (run off) semakin tinggi, sehingga secara langsung berdampak pada banjir permukaan, terutama pada saat curah hujan tinggi.

\section{Kesimpulan dan Saran}

Hasil penelitian dapat disimpulkan bahwa perubahan penggunaan lahan terbangun pada kawasan daerah aliran sungai Maros mengalami peningkatan yang cukup tinggi, dimana lahan kebun yang berubah menjadi permukiman sebesar 18,4 ha. Sedangkan sawah yang berubah menjadi permukiman sebesar 3,68 ha dari tahun 2015 ke tahun 2019. Pengaruh perubahan penggunaan lahan terbangun kuat dan signifikan terhadap peningkatan luas genangan banjir pada kawasan daerah aliran sungai Maros. Hasil temuan pada penelitian ini disarankan menjadi bahan masukan bagi pemerintah daerah Kabupaten Maros, khususnya dinas terkait dalam rangka mengendalikann lajunya pertumbuhan lahan terbangun khususnya pada wilayah daerah aliran sungai Maros.

\section{Daftar Pustaka}

Apriliawaty, A. (2016). Studi Pemanfaatan Ruang DAS Suli Kecamatan Suli Kabupaten Luwu. Skripsi. Jurusan Teknik Perencanaan Wilayah dan Kota, Fakultas Sains dan Teknologi Universitas Islam Negeri Alauddin Makassar

Abil, A., Latief, R., \& Yahya, I. (2020). Strategi Pengendalian Perkembangan Permukiman Disepanjang Sungai Tallo Kelurahan Rapokalling Kecamatan Tallo Kota Makassar. Journal of Urban Planning Studies, 1(1), 098-104. Diambil dari https://ejournalfakultasteknikunibos.id/index.php/j ups/article/view/27

Arikunto, S. (2013). Prosedur Penelitian: Suatu Pendekatan Praktik. Jakarta: Rineka Cipta.

Asdak. C. (2004). Hidrologi dan Pengelolaan Daerah Aliran Sungai. Yogyakarta: Gadjah Mada University Press.

Buraerah, M. F., Rasyidi, E. S., \& Sandi, R. (2020). Pemetaan Perubahan Penggunaan Lahan Di Wilayah Kabupaten Takalar Tahun 1999-2019
Menggunakan Sistem Informasi Geografis. Ecosystem, 20(1).

Cahyani Mokoginta, R., Syafri, S., \& Jufriadi, J. (2021). Alih Fungsi Lahan Pertanian Di Kawasan Jalan Hertasning Baru Kelurahan Kassi-Kassi Kota Makassar. Journal of Urban Planning Studies, 1(2), 204-214. https://doi.org/10.35965/jups.v1i2.65

Dewan Riset Nasional Kelompok II, Sumberdaya Alam dan Energi. (1994). Kebutuhan Riset dan Koordinasi Pengelolaan Sumberdaya Air di Indonesia. Jakarta : Dewan Riset Nasional.

Kodoatie, Robert, J dan Roestam Sjarief. (2006): Pengelolaan Bencana Terpadu. Jakarta: Penerbit Yarsif Watampone.

Lee, R. (1998). Hidrologi Hutan. Yogyakarta: Gadjah Mada University Press.

Lillesand, T.M, dan R.W. Kiefer. (1997). Pengindraan Jauh dan Interpretasi Citra. Cetakan Ketiga. Yogyakarta: Gajah Mada University Press.

Nasution. (2006). Metode Research (Penelitian Ilmiah). Jakarta: Bumi Aksara.

Oktarian, Deni. (2016). Analisis Spasial Perubahan Penggunaan Lahan Das Babon Hulu Terhadap Debit Puncak Sungai Babon Jawa Tengah, Skripsi. Jurusan Geografi Fakultas Ilmu Sosial Universitas Negeri Semarang.

Savitri, Asri. (2007). Kajian Pemanfaatan Ruang Dalam Kaitannya Dengan Resiko Banjir Di Kabupaten Bandung. Institut Pertanian Bogor

Sitorus SRP. (2004). Evaluasi Sumberdaya Lahan. Bandung: Tarsito Press.

Singarimbun, Masri dan Sofian Effendi. 1989. Metode Penelitian Survei. Jakarta. LP3ES

Soehartono, Irawan. (2008). Metode Penelitian Sosial. Bandung: PT. Remaja Rodaskarya

Sudjana, N. (2001). Metode Statistika. Bandung: Tarsito.

Sugiyono. (2004). Metode Penelitian Bisnis. Bandung : Alfabeta.

Sugiyono. (2012). Metode Penelitian Kualitatif, Kuantitatif, dan R \& D. Bandung: Penerbit Alfabeta.

Sukamto, R.. \& Supriatna, S. (1982). Geologi Lembar Ujung Pandang, Bantaeng dan Sinjai, Sulawesi skala 1:250.000. Bandung: Pusat Penelitian dan Pengembangan Geologi.

Surya, B., Hadijah, H., Suriani, S., Baharuddin, B., Fitriyah, A. T., Menne, F., \& Rasyidi, E. S. (2020). Spatial Transformation of a New City in 20062020: Perspectives on the Spatial Dynamics, Environmental Quality Degradation, and SocioEconomic Sustainability of Local Communities in Makassar City, Indonesia. Land, 9(9), 324.

Syafri, S., Surya, B., Ridwan, R., Bahri, S., Rasyidi, E. S., \& Sudarman, S. (2020). Water Quality Pollution Control and Watershed Management Based on Community Participation in Maros City, South Sulawesi, Indonesia. Sustainability, 12(24), 10260.

Usman, H. \& Akbar Purnomo S. (2011). Pengantar Statistika. Jakarta: PT Bumi Aksara. 
Undang-undang nomor 26 tahun 2007 tentang penataan Ruang

Woube, M. (1999). Flooding and Sustainable LandWater Management in The Lower Baro-Akobo River Basin, Ethiopia. Applied Geography 19: 235-251 